\title{
Changes in cellularity of Wistar rats bone marrow treated with fructose
}

\author{
Tatiele Estefâni Schönholzer ${ }^{*}$, Carolina Abreu Miranda, Betina Beatriz Mielke, Lusnaiara Rodrigues Lima, \\ Kleber Eduardo de Campos, Paula Cristina de Souza Souto \\ From 20th Brazilian Diabetes Society Congress \\ Porto Alegre, Brazil. 11-18 November 2015
}

\section{Background}

Fructose is a monosaccharide and is an important component of our diet. Children and young people consume foods low in nutrients and high in sugar, around 30\% daily, drawing attention to the increase in obesity and chronic diseases in populations. During ontogeny, bone marrow supports the formation and development of cells. The functioning of the immune system depends on several nutrients that have important roles in the body, and its deficiency leads to depression of the immune system. It is relevant to study a young animal model before an intake of fructose, standardizing the porcentage used and the treatment time.

\section{Objective}

The objective of this study was to evaluate the relationship of fructose diet and possible changes in cellularity of bone marrow of Wistar rats.

\section{Materials and methods}

Wistar male rats were used. At 42 days of age they were divided in two groups: a) control group $(C, n=7)$ : rats that received standard diet and filtered water without addition of other substances b) Group fructose (F, n=8): rats which received standard diet and filtered water with addition of $7 \%$ fructose. The animals were weighed weekly. Was analyzed biochemical parameters for monitoring monthly blood glucose. At the end of treatment (day 90) they were sedated and euthanized. Was analyzed the immunological parameters of the bone marrow (bone marrow aspirate), for total cell count (Neubauer chamber) and differential count and myeloid/erythroid lineage. Statistical analysis was done through the
Student $t$ test, analysis of variance (ANOVA) and Multiple Comparison Test Dunnett. Values were considered statistically different when $\mathrm{p} \leq 0.05$.

\section{Results}

The animals treated with fructose showed a hypercellular bone marrow with an increase in the erythroid and myeloid lineages (low neutrophils and leukocytosis) and also in myeloid/erythroid lineage. As for monthly blood glucose, the fructose group, there was a significant increase in the first month experiment with decrease in three months, compared to the control.

\section{Conslusion}

The results showed that the percentage of fructose used was not sufficient to induce hyperglycemia in animals, but its ingestion resulted in low neutrophils and leukocytosis, howing that even at low doses fructose caused changes in hematopoiesis.

Published: 11 November 2015

doi:10.1186/1758-5996-7-S1-A130

Cite this article as: Schönholzer et al:: Changes in cellularity of Wistar rats bone marrow treated with fructose. Diabetology \& Metabolic Syndrome 2015 7(Suppl 1):A130.

* Correspondence: tatischonholzer@gmail.com

UFMT, Barra do Garças, Brazil

(c) 2015 Schönholzer et al. This is an Open Access article distributed under the terms of the Creative Commons Attribution License (http://creativecommons.org/licenses/by/4.0), which permits unrestricted use, distribution, and reproduction in any medium, provided the original work is properly cited. The Creative Commons Public Domain Dedication waiver (http://creativecommons.org/ publicdomain/zero/1.0/) applies to the data made available in this article, unless otherwise stated. 